Working

Paper

Department

of Economics

$\mathrm{Ca}^{\prime}$ Foscari University of Venice

Gabriella Berloffa

Agar Brugiavini

Dino Rizzi

Health, Welfare and Inequality 


\title{
Health, Welfare and Inequality
}

\author{
Gabriella Berloffa \\ University of Trento \\ Agar Brugiavini \\ University of Venice - SSAV, Scuola Studi Avanzati in Venezia \\ Dino Rizzi \\ University of Venice - SSAV, Scuola Studi Avanzati in Venezia
}

\begin{abstract}
This paper uses data from the Health and Retirement Study (HRS) to study the relationship between health status and economic welfare at household level. We develop a model to estimate the welfare cost of ill health by exploiting the methodology of the equivalence scales. The crucial variables in this approach are, besides the health status (measured in several dimensions), the economic decisions of the household which can be directly related to health conditions, such as health-related expenses. By estimating a demand system we derive healthequivalence scales to learn about the cost of health conditions on economic welfare, controlling for other covariates. Our estimates suggest that - when taking account of health the welfare of households in poor health drops substantially and inequality increases. There are important social welfare costs associated with differences in the health status of the elderly in the USA.
\end{abstract}

\section{Keywords}

welfare cost, health, inequality

\section{JEL Codes}

$\mathrm{I} 12, \mathrm{I} 31, \mathrm{~J} 14$

Address for correspondence:

Agar Brugiavin

Department of Economics Ca' Foscari University of Venice Cannaregio 873, Fondamenta S.Giobbe 30121 Venezia - Italy

Phone: $(++39) 0412349162$

Fax: (++39) 0412349210 e-mail: brugiavi@unive.it

This Working Paper is published under the auspices of the Department of Economics of the Ca' Foscari University of Venice. Opinions expressed herein are those of the authors and not those of the Department. The Working Paper series is designed to divulge preliminary or incomplete work, circulated to favour discussion and comments. Citation of this paper should consider its provisional character.

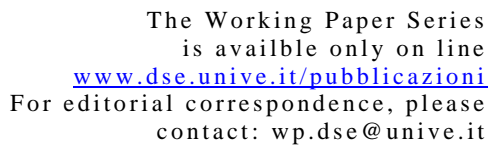

The Working Paper Series

is availble only on line www.dse.unive.it/pubblicazion For editorial correspondence, please contact:wp.dse@unive.it

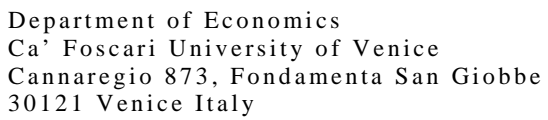

Department of Economics

Ca' Foscari University of Venice

Cannaregio 873, Fondamenta San Giobbe

30121 Venice Italy

Fax: ++390412349210 


\section{Introduction}

This paper uses the HRS (Health and Retirement Study) to examine the relationship between health status and economic welfare at the household level. The terminology and the intuition go along the lines developed by the equivalence scale literature: while in that case the focus is on the welfare cost brought about by the presence of children, and more generally demographics, we develop a model to estimate the welfare cost of coping with poor health.

To this end we exploit several dimensions of households behavior available in the HRS, which investigates different aspects of life for the ageing population in the USA. A recent novelty of this survey is that, along with the traditional health and socio-economic variables (CORE questionnaire), a number of variables providing information on expenditures on various items are also collected in a supplement (CAMS).

We cannot document paths to poverty and bad health and we cannot investigate the direction of causality between health and economic welfare (Smith, 1999 and 2002; Adda, Banks and von Gaudecker, 2005), because we do not have enough waves of the data or even data linking parents and children (Case, Lubotsky and Paxson, 2002), which would allow us to identify some of the relevant structural parameters of this relationship. Hence we focus the attention on the cross sectional distribution of welfare in the sample as determined by health conditions, exploiting the (short) panel nature of the data.

The first part of the paper is devoted to methodological issues as well as to the definition of "health outcomes" and to the ongoing debate on health inequality (Skinner and Zhou, 2004). The link between economic performance and health outcomes can be investigated by making use of the actual survival of individuals (Deaton , 2001) or of various indexes of health conditions (Currie and Madrian, 1999, Smith 1999 and 2002, Skinner and 
Zhou, 2004). The HRS offers a wide variety of health measures including the subjective self-reported health status.

The theoretical model clarifies how health enters the indirect utility function of the household and allows us to choose an actual measure of health which can be assigned to each household. As for economic welfare we will follow the tradition that recognizes income (total expenditure) as a starting point in the measurement of well being. However, household welfare indicators have to account for differences in demographic composition and health conditions. Therefore we derive an 'equivalent income' measure of wellbeing based on economic decisions of the household, which can be directly related to health conditions, such as health-related expenses.

Our data set contains information on various expenditure categories and medical expenditures, which we use to estimate a demand system: we argue that these expenditures items, taken jointly, are relevant in revealing the effects of health on welfare. The focus of the paper is the measurement of the indirect effects of ill-health on utility implied by changes in the structure of the cost function, hence we neglect any direct impact that different health conditions may have on well-being.

Section 2 contains both the main set up of the model, where household health conditions are used to derive an equivalent household income, and some elements of the empirical implementation. Section 3 discusses measurement issues and provides a brief description of the data, focusing the attention on the variables of interest: health status and expenditure measures. Section 4 presents the econometric estimates of health-related equivalence scales, Section 5 shows the implied equivalent incomes and it discusses the results in terms of inequality. Section 6 draws some conclusions.

\section{Health Inequality and Health Equivalence Scales- HES}

There is a rich literature based on the relationship between health and economic behaviour, investigating the well known "health-income 
gradient”, but, to our knowledge, only few contributions exist on the welfare costs of poor health conditions ${ }^{1}$.

The theoretical background is based on the notion that, at a micro level, health enters the utility function of individuals, e.g. in the form of a stock ${ }^{2}$. Models based on the "health-as-a-stock" assumption derive dynamic conditions that can be analyzed and tested in a dynamic context: the identifying strategy often hinges on unexpected shocks to health that affect life cycle variables. One might need in this case a very long history of health events dating back to childhood (Case, Lubotsky and Paxson, 2002; Smith, 2002), in order to test for causality it would be necessary also to specify the full joint data generating process for income and health (Adda, Banks and von Gaudecker, 2005) ${ }^{3}$.

In a broader health economics perspective, several authors have addressed the issue of "effectiveness", i.e. how much health care spending is reflect in better health outcomes, particularly in the USA. One strand of this literature has looked at a more specific question: which groups in the population account for the bulk of health care spending in a country? If it is high income people, or more educated people, the evidence would point to relevant socio economic disparities, which cannot be mitigated by increasing health care spending ${ }^{4}$.

The ongoing debate on the relationship between inequality in health care expenditures and inequality in health outcomes (and their relative strength) obviously involves studying carefully expenditure data, the utilization of

${ }^{1}$ See Wagstaff (1986 and 1991) and Williams (1997). Currie and Madrian (1999) provide a survey in this area of research, relating to labor supply decisions.

${ }^{2}$ Grossman (1972a and 1972b).

${ }^{3}$ Adda, Banks and von Gaudecker, 2005, provide a complete set up for testing the assumption that positive income innovations relate to health improvements in cohort data.

${ }^{4}$ See for example Le Grand (1978, 1982), Le Grand et. al. (2001), Lee, McClellan and Skinner (2004) and Battacharya and Lakdawalla (2004). 
effective health care and its quality (Baicker and Chandra, 2004; Skinner and Zhou, 2004).

In this paper we focus on a micro level investigation based on a short panel of households (Health and Retirement Study 2001 and 2003) and we contribute to one aspect of this debate, by providing fresh evidence on the health-income gradient based on consumption behaviour. On the basis of our data we cannot say if the effect of ill-health on welfare can be explained by a lack of access to care, forcing the household to bear out-of-pocket expenses, we can however provide a coherent set of estimates of expenditure decisions (including expenditure on health goods), conditional on health outcomes. From these we can infer the "true" cost of health for the sample under investigation.

In line with this approach it is appropriate to assume a static one-period decision model where, in principle, household welfare derives from both the utility of health and the utility of consumption. However, we do not attempt to separately identify the direct effect of health on utility, rather our model is based on a health-conditional cost function, from which we obtain in turn a health-deflated level of household income. In this respect the derivation of the demand for different commodities - including healthrelated goods - follows the two-stage budgeting approach and it is conditional on life cycle variables. In other words we measure the effects of ill-health on the marginal valuation of the different commodities entering a given basket.

From an empirical point of view, the concern for the endogeneity issue, i.e. for the fact that an underlying factor - say socio-economic status - jointly determines resources and health, is also mitigated by the fact that our health measures are obtained from the HRS-CORE questionnaire, which is collected one year before the HRS-CAMS, where the expenditure items are collected. Hence health can be regarded as pre-determined vis-à-vis expenditure choices. 
In order to explain how we estimate the relationship between health and welfare we need to specify the underlying consumer's problem. Suppose that each household $h$ is characterised by a utility function defined over household economic welfare index $\left(y_{h}^{E}\right)$, where $y_{h}^{E}$ will be specified as “equivalent income” in what follows. By assuming a standard specification of the utility function, the household welfare is:

$$
v_{h}=U\left(y_{h}^{E}\right)=\ln y_{h}^{E}
$$

Household economic welfare could depend on household demographics $\left(a_{h}\right)$, on household income $(y h)$, on commodity prices and on health status. The household economic welfare index $y_{h}^{E}$, is then obtained by rescaling the actual monetary measure of income $\left(y_{h}\right)$ by a scale which accounts for household characteristics $s\left(a_{h}\right)$ and by a scale of the health of each household $s\left(H_{h}\right)$, so that:

$$
v_{h}=\ln y_{h}^{E}=\ln y_{h}-\ln s\left(a_{h}\right)-\ln s\left(H_{h}\right)=\ln \left(\frac{y_{h}}{s\left(a_{h}\right) s\left(H_{h)}\right.}\right)
$$

Note that the two scales are assumed to be separable and therefore we simply take the product of the two. Suppose that the expenditure function $y h$ $=c\left(v h, p, a_{h}, H_{h}\right)$ is defined by a demand system $\operatorname{AIDS}^{5}$,i.e.:

$$
\ln \left(\frac{y_{h}}{s\left(a_{h}\right) s\left(H_{h)}\right.}\right)=\ln \left(\frac{c\left(v_{h}, p, a_{h}, H_{h}\right)}{s\left(a_{h}\right) s\left(H_{h}\right)}\right)=A\left(p, a_{h}, H_{h}\right)+v_{h} B(p)
$$

where $p=\left[p_{i}, i=1, \ldots, N\right]$ is the vector of prices of commodities which have been purchased. The two functions can be further specified as:

\footnotetext{
${ }^{5}$ Almost Ideal Demand System, Deaton and Muellbauer (1980a, 1980b).
} 


$$
\begin{gathered}
A\left(p, a_{h}, H_{h}\right)=\alpha_{0}+\sum_{k=1}^{N} \alpha_{k} \ln p_{k}+\frac{1}{2} \sum_{k=1}^{N} \sum_{j=1}^{N} \gamma_{k j}^{*} \ln p_{k} \ln p_{j} \\
+\sum_{k=1}^{N} \sum_{m=1}^{M} \lambda_{k m} \ln p_{k} a_{m h}+\sum_{k=1}^{N} \sum_{l=1}^{L} \eta_{k l} \ln p_{k} H_{l h}
\end{gathered}
$$

$$
B(p)=\beta_{0} \prod_{k=1}^{N} p_{k}^{\beta_{k}}
$$

Note that the scale-terms only enter the function A.

We define the equivalence scales as :

$$
\ln s\left(a_{h}\right)=\sum_{m=1}^{M} \lambda_{m} a_{m h}
$$

where $a_{h}=\left[a_{m h}, m=1, \ldots, M\right]$ is the vector of household characteristics $a_{m h}$ for the household $h$ (e.g..: gender of the head of the household, age of the head of the household, geographical location, etc..), and:

$$
\ln s\left(H_{h}\right)=\sum_{l=1}^{L} \lambda_{l} H_{l h}
$$

where $H_{h}=\left[H_{l h}, l=1, \ldots, L\right]$ is the vector of health outcomes $H l h$ for household $h$.

By taking the derivatives of equation (7) with respect to $\ln p_{i}$ we obtain the budget share for the $i$-th commodity:

(8)

$\left.w_{i h}=\alpha_{i}+\sum_{j} \gamma_{i j} \ln p_{j}+\beta_{i}\left[\ln y_{h} / P_{h}\right)\right]+\sum_{m=1}^{M}\left(\lambda_{m i}-\beta_{i} \lambda_{m}\right) a_{m h}+\sum_{l=1}^{L}\left(\lambda_{l i}-\beta_{i} \lambda_{l}\right) H_{l h}$

where $P_{h}=A\left(p, a_{h}, H_{h}\right)$ is again an aggregate price index of relative prices for household $h$.

Not that in the estimation we can only obtain values for the combined coefficients: 


$$
\begin{gathered}
\theta_{m i}=\lambda_{m i}-\beta_{i} \lambda_{m} \\
\pi_{i l}=\lambda_{l i}-\beta_{i} \lambda_{l}
\end{gathered}
$$

as functions of household's demographic characteristics $a_{m h}$ and health characteristics $H_{l h}$. Therefore the estimation of the budget shares as described in (8) does not directly deliver specific scales for each demographic characteristic or health outcome, but a combination of parameters. However, we could add a second stage to the estimation on the basis of the following idea. If the terms $\lambda_{m i}$ and $\lambda_{l i}$ in (9) and (10) are regarded as zero-sum deviations from the general equivalence scale (i.e. the parameters $\lambda_{m}$ and $\lambda_{l}$ ), then the latter can be retrieved once we know the estimates for the parameters $\theta_{m i}, \pi_{l i}$ and $\beta_{i}{ }^{6}$.

The actual implementation of the estimation procedure starting form equation (8) requires knowledge of the price vector. Although we use the CPI for the seven consumption categories defined above to obtain real expenditures, the time variation of prices does not allow us to separately identify price elasticities ${ }^{7}$. If we apply the conventional normalization carried out in cross sectional data, such that $p_{i}=1$ and $\ln p_{i}=0$, the budget shares of interest are :

$$
\begin{gathered}
w_{i h}=\alpha_{i}+\beta_{i}\left[\ln y_{h}-\ln s\left(a_{h}\right)-\ln s\left(H_{h}\right)\right] \\
\boldsymbol{w}_{\boldsymbol{i h}}=\boldsymbol{\alpha}_{\boldsymbol{i}}+\boldsymbol{\beta}_{\boldsymbol{i}} \ln \boldsymbol{y}_{\boldsymbol{h}}+\sum_{\boldsymbol{m}=1}^{M} \boldsymbol{\theta}_{\boldsymbol{m} \boldsymbol{i}} \boldsymbol{a}_{\boldsymbol{m} \boldsymbol{h}}+\sum_{l=1}^{L} \boldsymbol{\pi}_{\boldsymbol{l i}} \boldsymbol{H}_{\boldsymbol{l h}}
\end{gathered}
$$

In this case we can show that by construction the general scales $s\left(a_{h}\right)$ behaves as an equivalence scale with respect to characteristics $a_{h}$, for a given health status.

In fact we can take the ratio:

${ }^{6}$ See also Patrizii and Rossi (1991). Note however that the "regressions" (10) and (11) cannot be implemented through an OLS procedure as residuals are non independent, therefore we resort to a GLS procedure in the parameter space.

${ }^{7}$ Price indexes vary across regional areas and expenditure categories, but we have only one time lag between 2001 and 2003. 


$$
\frac{c\left(v_{h}, p, a_{h}, H_{h}\right)}{c\left(v_{h}, p, a_{R}, H_{h}\right)}=\frac{\exp \left(v_{h}\right) s\left(a_{h}\right) s\left(H_{h}\right)}{\exp \left(v_{h}\right) s\left(a_{R}\right) s\left(H_{h}\right)}=s\left(a_{h}\right)
$$

where we normalize in such a way that the scale takes value one for the reference household $s\left(a_{R}\right)=1$.

Most interesting for our exercise, given $a_{h}, s\left(H_{h}\right)$ behaves as an equivalence scale based on health conditions, because:

$$
\frac{c\left(v_{h}, p, a_{h}, H_{h}\right)}{c\left(v_{h}, p, a_{h}, H_{R}\right)}=\frac{\exp \left(v_{h}\right) s\left(a_{h}\right) s\left(H_{h}\right)}{\exp \left(v_{h}\right) s\left(a_{h}\right) s\left(H_{R}\right)}=s\left(H_{h}\right)
$$

where we normalize so that $s\left(H_{R}\right)=1$ for the reference health level. It is useful in our context to define $H_{R}$ as the maximum value that the health indicator can take, such that $s\left(H_{\max }\right)=1$ when health is "excellent".

The combined equivalence scale for a generic household $h$ depends on both scales as follows:

$$
\frac{c\left(v_{h}, p, a_{h}, H_{h}\right)}{c\left(v_{h}, p, a_{R}, H_{R}\right)}=\frac{\exp \left(v_{h}\right) s\left(a_{h}\right) s\left(H_{h}\right)}{\exp \left(v_{h}\right) s\left(a_{R}\right) s\left(H_{R}\right)}=s\left(a_{h}\right) s\left(H_{h}\right)=S\left(a_{h}, H_{h}\right)
$$

\section{The relationship between health and expenditure on health- goods}

This paper uses the HRS (Health and Retirement Study). The HRS is a biennial panel starting in 1992, in the year 2000 it covered cohorts of 1947 or earlier, with approximately 20000 subjects aged 50 and over. The CAMS were conducted in 2001 and 2003 (between CORE surveys), for the 2001 CAMS questionnaire were sent to 5000 people drawn from HRS 2000, in 2003 they were sent to 4156 of the respondents of 2001. Due to death and other attrition problems the 2003-CAMS early release contains 3254 respondents which we linked to the 2001 respondents. A detailed description of this supplement can be found in Hurd and Rohwedder (2005) and in RAND (2005). We focus on the consumption section of the supplement, the most knowledgeable person in the household is asked about spending of the household: there are 32 consumption categories recorded, 
we only make use of spending on 26 non-durable items. Also, we group finer categories into broader categories as follows:

- Free time spending (trips, vacation, entertainment, hobbies etc..)

- Clothing

- $\quad$ Food (in and out)

- Transportation and vehicle services (including gasoline)

- Home repairs and maintenance - household items (including rent)

- Health related expenditures (out of pocket expenses on drugs, medications, health services, medical supply etc.., not covered by insurance)

- Housing services (including utilities such as electricity, water charges etc..)

Table 1 shows the average and standard deviation of the budget shares of these expenditure items in 2001 and 2003 together (in real terms). Some households report expenditures on one consumption category only, these observations are not informative for our analysis and we prefer to include only households who have at least two non-zero expenditure items in their budget $^{8}$. Table 1 clearly shows that health-related expenditures are a substantial fraction of household's budget, the estimated mean share is higher than the one observed for clothing and for transportation: a spending pattern which is not surprising for this age group.

\footnotetext{
${ }^{8}$ We excluded 411 observations through this selection.
} 
Table 1 Mean Budget Share in the HRS (CAMS) 2001 and 2003

\begin{tabular}{||l|l|l||}
\hline Budget Share & Mean & $\begin{array}{l}\text { Standard } \\
\text { Deviation }\end{array}$ \\
\hline health goods & 0.1218 & 0.1405 \\
\hline food & 0.1680 & 0.1596 \\
\hline house services & 0.2158 & 0.1701 \\
\hline other house expenses & 0.2613 & 0.2390 \\
\hline free time & 0.0969 & 0.1273 \\
\hline clothing & 0.0573 & 0.0749 \\
\hline transportation & 0.0785 & 0.0956 \\
\hline
\end{tabular}

As for the health measure, the HRS has information on subjective as well as objective (self-reported) health measures. The former is the usual "how are you?"9 question while the latter involves questions - in several dimensions - which record the ability to perform activities (climbing stairs, walking etc..) and current illnesses or health problems (hart and lung conditions etc..). Furthermore we can rely on questions concerning disability ${ }^{10}$, although these may not correspond to actual physical disability, but only to an economic condition (collecting the benefit), they do provide some valuable information about the overall health condition of the respondent. In the empirical analysis we make use of three main health indicators, all recorded at individual level:

(1) Subjective health, the scale goes from 1 (excellent) to 5 (very poor), we rescale the coding between 1 and 0 ;

(2) Activities of Daily Living, particularly ADL3, which looks at three main abilities (dressing, bathing and eating). The index ranges between 0 (no limitations) and 3 (inability to perform all three activities);

(3) Self-reported disabled.

The following Table 2 shows the distribution of the self-reported subjective health condition, while Table 3 shows the distribution of ADL3 .

\footnotetext{
9 "Would you say your health is excellent, very good, good, fair, or poor?"

${ }^{10}$ In the year 2000 question (H00G_R) and in 2002 (H02J_R), both from the CORE.
} 
TABLE 2. Distribution of self-reported subjective health status

\begin{tabular}{||l|c|c|c|c||}
\hline $\begin{array}{l}\text { Subjective health } \\
\text { Index }\end{array}$ & $\begin{array}{c}\text { CORE } \\
\mathbf{2 0 0 0} \\
\mathbf{\%}\end{array}$ & $\begin{array}{l}\text { CORE } \\
\mathbf{2 0 0 2} \\
\mathbf{\%}\end{array}$ & $\begin{array}{l}\text { CAMS } \\
\mathbf{2 0 0 1} \\
\mathbf{\%}\end{array}$ & $\begin{array}{l}\text { CAMS } \\
\mathbf{2 0 0 3} \\
\mathbf{\%}\end{array}$ \\
\hline poor (0.00) & 9.52 & 9.19 & 6.73 & 5.71 \\
\hline fair (0.25) & 18.81 & 19.92 & 17.26 & 17.68 \\
\hline good (0.50) & 30.16 & 31.61 & 29.91 & 31.77 \\
\hline very good (0.75) & 28.88 & 27.99 & 31.77 & 32.02 \\
\hline excellent (1.00) & 12.64 & 11.29 & 14.33 & 12.82 \\
\hline Total & & & & \\
\hline Number of observations & 19572 & 18156 & 5811 & 5062 \\
\hline \hline
\end{tabular}

\section{TABLE 3: Distribution of ADL3}

\begin{tabular}{||c|c|c|c|c||}
\hline ADL3 Index & $\mathbf{2 0 0 0}$ & $\mathbf{2 0 0 2}$ & $\mathbf{2 0 0 1}$ & $\mathbf{2 0 0 3}$ \\
\hline & & & & \\
\hline $\mathbf{0}$ & 85.89 & 85.83 & 90.19 & 90.30 \\
\hline $\mathbf{1}$ & 7.93 & 7.66 & 6.71 & 6.16 \\
\hline $\mathbf{2}$ & 3.74 & 3.99 & 2.39 & 2.75 \\
\hline & 2.44 & 2.53 & 0.71 & 0.79 \\
\hline Total & & & & \\
\hline number of observations & 100.00 & 100.00 & 100.00 & 100.00 \\
\hline
\end{tabular}

While the health measure is available at the individual level, expenditure and therefore welfare, are reported at household level. Hence we need to define an health indicator for the household. Let $H_{h c}$ represent the subjective health of the individual $C$ in household $h$ (with $c=1, \ldots, C$ ), it can be aggregated at the household level on the basis of a 'selfishbehaviour' assumption, i.e. by simply taking the average of individuals' health:

$$
\Gamma_{h}=\frac{1}{C} \sum_{c=1}^{C} \frac{H_{h c}}{H_{\max }}
$$

where $H_{\max }$ represents the maximum level of health (i.e. someone in excellent health conditions). For example, in our data this corresponds to the value one. It is clear that the 'selfish' attitude is due to orthogonality 
between the contribution of one's health on total health and the level of health of relatives in the household:

$$
\frac{\partial \Gamma_{h}}{\partial H_{h c}}=\frac{1}{C H_{\max }}
$$

The geometric mean exhibits a more 'altruistic' attitude, however in this paper we are mainly concerned with the overall effect on expenditure decisions rather than capturing the cross effects of the composition of health within the household, therefore we opt for the arithmetic mean.

Since the main point of the paper is to exploit the differences in the cost of "health-goods" in relation to the health conditions of the household, we motivate this study by first looking at the patterns of these covariates in the data. In the CAMS sample about ten percent of the households do not report any health expenditures, Table 4 shows the percentage distribution of households with zero health expenditures by aggregated household health status.

Table 4. Distribution of households with zero health expenditures

\begin{tabular}{||l|l||}
\hline $\begin{array}{l}\text { Aggregated household } \\
\text { health index } \\
\text { (within household mean) }\end{array}$ & $\begin{array}{l}\text { Percentage with No } \\
\text { Health } \\
\text { Expenditure }\end{array}$ \\
\hline & \\
\hline 0.000 & 18.02 \\
\hline 0.125 & 18.52 \\
\hline 0.250 & 13.64 \\
\hline 0.375 & 6.82 \\
\hline 0.500 & 9.50 \\
\hline 0.625 & 4.48 \\
\hline 0.750 & 7.84 \\
\hline 0.875 & 7.51 \\
\hline 1.000 & 12.93 \\
\hline & \\
\hline Total & 9.51 \\
\hline \hline
\end{tabular}

This percentage is higher for households in "poor health" which seems puzzling at first: there are several explanations for this evidence, including 
the possibility that although there are positive health expenditures these are fully covered by insurance ${ }^{11}$. In any event, mean and median budget shares of health costs are higher for households in poor health, when taking moments both conditional and unconditional on spending on health-goods.

Table 5. Mean and Median Budget Share on Health Goods by Health Status

\begin{tabular}{|l|l|l|l|l||}
\hline $\begin{array}{l}\text { aggregated } \\
\text { health } \\
\text { index }\end{array}$ & $\begin{array}{l}\text { unconditional } \\
\text { median }\end{array}$ & $\begin{array}{l}\text { unconditional } \\
\text { mean }\end{array}$ & $\begin{array}{l}\text { conditional } \\
\text { median }\end{array}$ & $\begin{array}{l}\text { conditional } \\
\text { mean }\end{array}$ \\
\hline$<\mathbf{0 . 4 0}$ & 0.091 & 0.151 & 0.114 & 0.174 \\
\hline $\begin{array}{l}\geq \mathbf{0 . 4 0} \text { and } \\
<\mathbf{0 . 7 0}\end{array}$ & 0.083 & 0.128 & 0.093 & 0.139 \\
\hline$\geq \mathbf{0 . 7 0}$ & 0.058 & 0.099 & 0.066 & 0.109 \\
\hline
\end{tabular}

Spending patterns on health-related goods are obviously affected by the existence of insurance coverage. In the HRS sample (individuals aged 50 and over) enrolment in Medicare is clearly relevant both for part A and for part B (57\% in the year 2000 participate to Medicare A, 95\% of these individuals is also covered by Medicare B). As for Medicaid approximately $8 \%$ of individuals is covered (mostly women, presumably dependent wives). A residual fraction of the sample is covered by other insurances. However participation to these plans does not drive to zero out-of-pocket health expenditures, also because many covered goods and services imply a substantial co-payment.

The stylized fact that this brief description highlights is that households in "poor health" spend a substantially higher proportion of their budget in health-related goods. We are confident that we can rule out a potential

\footnotetext{
${ }^{11}$ For example through Medicare or Medicaid.

${ }^{12}$ For simplicity we have combined the nine categories of the aggregate health index into three main brackets on the basis of the density over these categories.
} 
alternative explanation, i.e. that households which self- report poor health conditions are not objectively unhealthy, but, simply because of their perception, they will be spending more than the average on healthcommodities. I.e. one might argue that preferences and pessimism drive both the answer to subjective health conditions and to health-related expenditures. A simple Ordered Probit analysis of the subjective health index on other self-reported objective measures (blood pressure, hart condition etc..) shows a high predictive power of the battery of objective variables $^{13}$. Hence subjective health conditions determine health-related expenditures largely on the basis of actual needs and not just on the basis of different preferences.

Furthermore, one could argue that, since health typically correlates with income (the well known socio-economic conditions -SES- gradient, Smith 2002) the differences described above are the result of the underlying income distribution. However a simple non parametric regression of the health budget share on total expenditure shows that the Engel curve is essentially flat, apart from the tails of the distribution (Figure 1). Hence the relationship of these expenditures to income cannot completely drive the correlation of health outcomes and the "health" budget share.

\footnotetext{
${ }^{13}$ Results are available from the authors upon request.
} 
Figure 1. Non parametric Engel curve of the "health-commodities" budget share

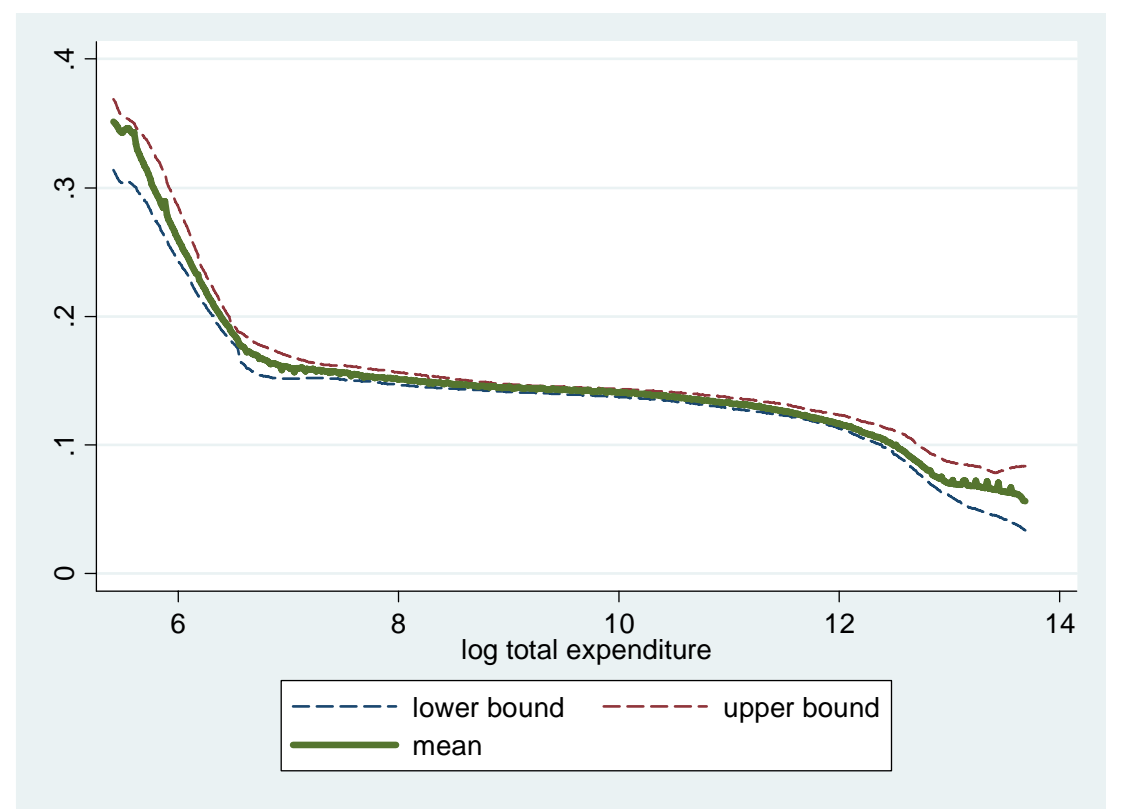

\section{Empirical set up and results}

The definition of budget shares provided in equation (13) above can be used to estimate equivalence scales in our data. The budget share of household $h$ is defined over its characteristics (or characteristics of the head of the household - such as age, or aggregation of characteristics - such as ADL). We restrict ourselves to households with one or two-persons, because different family compositions may imply a complex combination of health outcomes, demographics, resources and consumption behaviour ${ }^{14}$. As we mentioned in Section 3 we select households with non-zero expenditures on at least two categories, the final estimation sample is described in Table A1 in the Appendix.

Demand system equations require to be simultaneously estimated: we make use of a 3SLS procedure where the set of explanatory variables is identical in all equations and it includes age of the head, gender of the head,

\footnotetext{
${ }^{14}$ We also exclude a few households with missing subjective health status.
} 
educational dummies and occupational dummies, the existence of health insurance, health-related variables and regional dummies ${ }^{15}$.

The reason to resort to 3SLS is because we treat total expenditure as an endogenous variable and we instrument total expenditure by a number of instruments including income and dummies for different types of income (see Blundell, Pashardes and Weber, 1993). In order to capture the effects of health on budget shares we use as controls also risk factors such as smoking and drinking habits, in fact inequality may result simply from differences in healthy living. Furthermore we control for the presence of medical insurance by introducing a dummy if participating Medicare, a dummy for Medicaid and a dummy for other Medical Insurances. In this set up the reference categories of dummy variables (or discrete variables) are relevant to construct equivalent incomes, in particular for health the reference category is Hmax (household health-level index between 0.7 and 1). For the other variables we choose a household whose members are couple, all members have secondary education and all members are in dependent employment.

Since we are dealing with panel data, observations will not be independent; hence we use a between-transformation in order to exploit the cross sectional variability of interest (for example differences in demographics between households which are fixed over time). It should be recalled that subjective health indexes and ADL measures refer to the COREquestionnaire of the year prior to the expenditure decision and therefore are predetermined in our regressions.

Results are presented in Table 6, where each column refers to one consumption category and the rows refer to selected explanatory variables ${ }^{16}$.

\footnotetext{
${ }^{15}$ Most dummies are defined as to show whether the relevant characteristic applies to one member of the household (e.g. low education_1) or to both members (e.g. low education_2).

${ }^{16}$ One consumption category (house expenditures) is omitted because, due to the adding-up restrictions, estimates of the parameters are automatically determined. Explanatory variables include occupational dummies, regional dummies etc...not shown for brevity.
} 
Log-real-expenditure has a negligible effect on the health-share, which suggest that this commodity is neither a necessity nor a luxury. This is line with what found in Figure 1, once we properly take account of the complete set of consumption decisions and of demographics, there is basically no relationship of health-related out-of-pocket expenditures to income. One could argue that the lack of correlation is totally due to the existence of medical insurance: however we already pointed out that people covered by Medicare might have to face substantial out-of-pocket expenses. Indeed of the insurance dummy variables included in the regression only Medicaid has a negative significant effect on the budget of health commodities.

In the "health-equation", the subjective-health aggregate index has a significant positive effect: those who report poor health conditions tend to spend more on health related commodities.

Other variables have a minor role in the medical expenses equation, apart from age (positive effect), the ADL3 dummies (positive effect) and drinking habits (negative effect). Interesting enough in our demand system educational dummies have a significant effect only on housing services and "free-time" expenditures, not on the health-budget share, hence our simultaneous equation system (controlling for health) does not lend support to the view that more educated people account for the larger fraction of health spending in the USA ${ }^{17}$. However it should be pointed out that the HRS sample looks at a selected group of the population, which may be not representative of the overall spending pattern of the American population and also has important differences in terms of educational attainments.

\footnotetext{
${ }^{17}$ See the discussion in Skinner and Zhou (2004) and Battacharya and Lakdawalla (2004)
} 
Table 6 Estimates of the demand system on HRS-CAMS 2001 and 2003. Based on between estimator 3SLS (Selected explanatory variables - standard errors in parentheses)

\begin{tabular}{|c|c|c|c|c|c|c|}
\hline & $\begin{array}{l}\text { Health } \\
\text { Goods }\end{array}$ & Food & $\begin{array}{l}\text { House } \\
\text { Services }\end{array}$ & $\begin{array}{l}\text { Free } \\
\text { Time } \\
\text { Goods }\end{array}$ & Clothing & Transport \\
\hline $\begin{array}{l}\text { Log of Real } \\
\text { Total } \\
\text { Expenditure }\end{array}$ & $\begin{array}{l}-0.007 \\
(0.027)\end{array}$ & $\begin{array}{l}-0.022 \\
(0.027)\end{array}$ & $\begin{array}{l}-0.007 \\
(0.033)\end{array}$ & $\begin{array}{l}0.101 \\
(0.028)\end{array}$ & $\begin{array}{l}0.023 \\
(0.015)\end{array}$ & $\begin{array}{l}-0.014 \\
(0.018)\end{array}$ \\
\hline Age & $\begin{array}{l}0.149 \\
(0.028)\end{array}$ & $\begin{array}{l}0.030 \\
(0.028)\end{array}$ & $\begin{array}{l}-0.063 \\
(0.033)\end{array}$ & $\begin{array}{l}-0.141 \\
(0.029)\end{array}$ & $\begin{array}{l}-0.037 \\
(0.033)\end{array}$ & $\begin{array}{l}-0.052 \\
(0.018)\end{array}$ \\
\hline Head is Male & $\begin{array}{l}-0.010 \\
(0.005)\end{array}$ & $\begin{array}{l}0.010 \\
(0.005)\end{array}$ & $\begin{array}{l}-0.001 \\
(0.006)\end{array}$ & $\begin{array}{l}0.016 \\
(0.005)\end{array}$ & $\begin{array}{l}-0.008 \\
(0.002)\end{array}$ & $\begin{array}{l}0.006 \\
(0.003)\end{array}$ \\
\hline $\begin{array}{lr}\text { One member } \\
\text { has } \\
\text { education }\end{array}$ & $\begin{array}{l}0.004 \\
(0.008)\end{array}$ & $\begin{array}{l}-0.003 \\
(0.008)\end{array}$ & $\begin{array}{c}0.024 \\
(0.010)\end{array}$ & $\begin{array}{l}-0.002 \\
(0.008)\end{array}$ & $\begin{array}{r}-0.004 \\
(0.004)\end{array}$ & $\begin{array}{l}-0.006 \\
(0.005)\end{array}$ \\
\hline $\begin{array}{l}\text { Both members } \\
\text { have low } \\
\text { education }\end{array}$ & $\begin{array}{l}-0.033 \\
(0.019)\end{array}$ & $\begin{array}{l}-0.007 \\
(0.019)\end{array}$ & $\begin{array}{l}-0.030 \\
(0.023)\end{array}$ & $\begin{array}{l}-0.012 \\
(0.019)\end{array}$ & $\begin{array}{l}-0.008 \\
(0.010)\end{array}$ & $\begin{array}{l}0.050 \\
(0.012)\end{array}$ \\
\hline $\begin{array}{l}\text { One member } \\
\text { is disabled }\end{array}$ & $\begin{array}{l}0.018 \\
(0.011)\end{array}$ & $\begin{array}{l}-0.003 \\
(0.011)\end{array}$ & $\begin{array}{c}0.002 \\
(0.013)\end{array}$ & $\begin{array}{l}-0.006 \\
(0.011)\end{array}$ & $\begin{array}{c}-0.001 \\
(0.006)\end{array}$ & $\begin{array}{r}-0.011 \\
(0.007)\end{array}$ \\
\hline $\begin{array}{l}\text { Both } \\
\text { members are } \\
\text { disabled }\end{array}$ & $\begin{array}{l}0.009 \\
(0.033)\end{array}$ & $\begin{array}{l}-0.057 \\
(0.033)\end{array}$ & $\begin{array}{c}0.065 \\
(0.039)\end{array}$ & $\begin{array}{c}0.031 \\
(0.033)\end{array}$ & $\begin{array}{r}-0.014 \\
(0.018)\end{array}$ & $\begin{array}{c}0.016 \\
(0.022)\end{array}$ \\
\hline $\begin{array}{l}\text { Subjective } \\
\text { health } \\
\text { "poor health” }\end{array}$ & $\begin{array}{l}0.046 \\
(0.007)\end{array}$ & $\begin{array}{l}0.015 \\
(0.007)\end{array}$ & $\begin{array}{l}-0.007 \\
(0.008)\end{array}$ & $\begin{array}{l}-0.052 \\
(0.007)\end{array}$ & $\begin{array}{l}-0.006 \\
(0.003)\end{array}$ & $\begin{array}{l}-0.007 \\
(0.004)\end{array}$ \\
\hline $\begin{array}{l}\text { Subjective } \\
\text { health } \\
\text { “fair health” }\end{array}$ & $\begin{array}{l}0.025 \\
(0.005)\end{array}$ & $\begin{array}{l}0.010 \\
(0.006)\end{array}$ & $\begin{array}{l}0.027 \\
(0.007)\end{array}$ & $\begin{array}{l}-0.022 \\
(0.006)\end{array}$ & $\begin{array}{l}-0.005 \\
(0.003)\end{array}$ & $\begin{array}{l}-0.001 \\
(0.003)\end{array}$ \\
\hline $\begin{array}{l}\text { One or both } \\
\text { members with } \\
\text { no more than } \\
\text { one ADL3 }\end{array}$ & $\begin{array}{l}0.014 \\
(0.009)\end{array}$ & $\begin{array}{l}0.0006 \\
(0.009)\end{array}$ & $\begin{array}{l}0.003 \\
(0.011)\end{array}$ & $\begin{array}{l}-0.011 \\
(0.009)\end{array}$ & $\begin{array}{l}-0.007 \\
(0.005)\end{array}$ & $\begin{array}{l}-0.004 \\
(0.006)\end{array}$ \\
\hline $\begin{array}{l}\text { One or both } \\
\text { members with } \\
\text { more than one } \\
\text { ADL3 }\end{array}$ & $\begin{array}{l}0.060 \\
(0.011)\end{array}$ & $\begin{array}{l}-0.019 \\
(0.011)\end{array}$ & $\begin{array}{l}-0.006 \\
(0.014)\end{array}$ & $\begin{array}{l}-0.031 \\
(0.012)\end{array}$ & $\begin{array}{l}-0.006 \\
(0.006)\end{array}$ & $\begin{array}{l}-0.012 \\
(0.007)\end{array}$ \\
\hline $\begin{array}{l}\text { Medicare } \\
\text { dummy }\end{array}$ & $\begin{array}{l}-0.003 \\
(0.007)\end{array}$ & $\begin{array}{l}-0.0001 \\
(0.007)\end{array}$ & $\begin{array}{l}0.006 \\
(0.009)\end{array}$ & $\begin{array}{l}0.004 \\
(0.007)\end{array}$ & $\begin{array}{l}-0.002 \\
(0.004)\end{array}$ & $\begin{array}{l}-0.011 \\
(0.005)\end{array}$ \\
\hline $\begin{array}{l}\text { Medicaid } \\
\text { dummy }\end{array}$ & $\begin{array}{l}-0.087 \\
(0.015)\end{array}$ & $\begin{array}{l}-0.016 \\
(0.015)\end{array}$ & $\begin{array}{l}0.044 \\
(0.019)\end{array}$ & $\begin{array}{l}0.038 \\
(0.016)\end{array}$ & $\begin{array}{l}0.013 \\
(0.008)\end{array}$ & $\begin{array}{l}-0.018 \\
(0.010)\end{array}$ \\
\hline $\begin{array}{l}\text { Other } \\
\text { Insurance } \\
\text { dummy }\end{array}$ & $\begin{array}{l}0.022 \\
(0.008)\end{array}$ & $\begin{array}{l}-0.023 \\
(0.008)\end{array}$ & $\begin{array}{l}0.022 \\
(0.010)\end{array}$ & $\begin{array}{l}-0.015 \\
(0.008)\end{array}$ & $\begin{array}{l}-0.009 \\
(0.004)\end{array}$ & $\begin{array}{l}0.032 \\
(0.005)\end{array}$ \\
\hline Smoking & $\begin{array}{l}-0.011 \\
(0.006)\end{array}$ & $\begin{array}{l}0.010 \\
(0.006)\end{array}$ & $\begin{array}{l}0.011 \\
(0.008)\end{array}$ & $\begin{array}{l}-0.023 \\
(0.006)\end{array}$ & $\begin{array}{l}-0.004 \\
(0.003)\end{array}$ & $\begin{array}{l}-0.0009 \\
(0.004)\end{array}$ \\
\hline Drinking & $\begin{array}{l}-0.011 \\
(0.005)\end{array}$ & $\begin{array}{l}0.006 \\
(0.005)\end{array}$ & $\begin{array}{l}-0.014 \\
(0.006)\end{array}$ & $\begin{array}{l}0.016 \\
(0.005)\end{array}$ & $\begin{array}{l}0.0008 \\
(0.003)\end{array}$ & $\begin{array}{l}-0.006 \\
(0.003)\end{array}$ \\
\hline
\end{tabular}


As for regional dummies (not shown) the West-South dummy seem to have a positive significant effect on the health-goods budget share. Although these dummies are just controlling for the region of residence, and not necessarily reflecting characteristics of the system where people receive health care (Skninner and Zhou, 2004), when used in a demand system, along with all the other variables, these dummies should reflect the characteristics of the supply of health care, including differences in prices.

For the other commodities log-real expenditure has the expected sign, in particular "free time" is positively related to "income". No clear pattern can be envisaged for the effect of subjective health on other commodities, apart from "free time activities", where the effect of ill health is negative.

Our estimates show a number of interesting facts: out-of-pocket health expenses are strongly affected by poor health and conditions (subjective) and by the existence of self-reported limitations in daily activities. They are not affected by income levels or educational levels or other demographics. The other commodity which is strongly affected by health conditions (but also by income levels) is spending on "free time goods". Given the age group represented in our sample, this points to important complementarities of these two consumption categories in households' budgets.

\section{The Implied Equivalence scales and Inequality: Beyond the Health- Income Gradient.}

The commodity-specific equivalence scales can be derived ex post, starting from the definition provided in equations (4) and (5) and by following the procedure described in equations (9) and (10) above, which applies a GLS regression in the parameter space, once the estimated parameters from the budget shares equations are known, hence delivering also a measure of dispersion.

Once we have available health-based equivalence scales these will allow us to study several aspects of the effects of health status which are usually 
neglected in analyses of economic welfare. As we argued in the introduction, much of the attention in the literature has focused on the direct correlation between health and resources (income or wealth), i.e. the health income gradient. However it is useful to measure income inequality while controlling for health conditions, a simple extension of our econometric analysis is to construct equivalent incomes which are based on a coherent measure of the costs of ill health.

The health-based equivalent income( at the household level) is derived by making use of the scale based on household subjective health conditions:

$$
y_{h}^{H}=\frac{y_{h}}{s\left(H_{h}\right)}
$$

This represents the income that household $h$ would need to reach its own welfare level (given its own demographic characteristics $a_{h}$ ), if that household had the health status of the reference household (i.e. the maximum health status). If the household does not enjoy excellent health, then the equivalence scale is larger than 1 and equivalent income is below actual money income: it is as if that household was effectively made poorer by a lower health status. A combined equivalent income, defined by equation (3) ca be obtained as:

$$
y_{h}^{E}=\frac{y_{h}}{s\left(a_{h}\right) s\left(H_{h}\right)}
$$

where the scale based on household demographics is also used. This is the income that household $h$ would need to be as well off as in its current situation evaluated at the demographics of the reference household and at the ‘excellent health’ status.

In all these cases equivalent income is a measure of household welfare (a positive monotonic transformation of utility).

A simple comparison of actual income and equivalent income provides evidence of the welfare cost of health. The distribution of this over different characteristics (say age) also gives indications of the incidence of these costs in different groups of the population. 
For simplicity we only report equivalence scales for some relevant dimensions in Table 7. The underlying estimates have been obtained through the "between estimator" and by making use of real expenditure. Table 7 shows that, other things being equal, the scale is highest (the household is "poorest") for the worse health conditions and is decreasing almost linearly as health conditions get closer to their maximum value (set equal to one).

This is a first important finding of our paper: if we consider two identical households in terms of income (with the same total expenditure) but different health conditions, our estimates say that the equivalent income of the household in poor health is approximately two thirds of the equivalent income of the healthy household. The ADL3 scale also shows a strong effect of ill-health on welfare, implying that a relevant "compensation" would be needed to provide such a household with the same level of welfare as a similar household with no limitations. Age is also playing a very important role in assessing differences in welfare: given the spending patterns of two otherwise identical households, older households have much lower welfare. 
TABLE 7: $\quad$ Implied equivalence scales

(based on between estimator- standard errors in parentheses)

\begin{tabular}{||l|l|l|l||}
\hline & & OLS & GLS \\
\hline Subjective health & Poor & 1.495 & $\begin{array}{l}1.621 \\
(0.334)\end{array}$ \\
\hline & Fair & 1.140 & $\begin{array}{l}1.267 \\
(0.141)\end{array}$ \\
\hline & & & \\
\hline Disabled & One member disabled & 1.046 & $\begin{array}{l}1.042 \\
(0.102)\end{array}$ \\
\hline & Both members disabled & 0.661 & $\begin{array}{l}0.806 \\
(0.279)\end{array}$ \\
\hline & & & 1.129 \\
& One or both members with \\
& no more than one inability & 1.109 & $(0.077)$ \\
\hline ADL3 & $\begin{array}{l}\text { One or both members with } \\
\text { more than one inability }\end{array}$ & 1.289 & $\begin{array}{l}1.274 \\
(0.325)\end{array}$ \\
\hline & & & \\
\hline & & 0.932 & 0.765 \\
& & 1 & 1 \\
\hline $\begin{array}{l}\text { Single-member } \\
\text { household }\end{array}$ & 60 & 1.246 & $\begin{array}{l}1.211 \\
(0.131)\end{array}$ \\
\hline Age & 70 & 1.508 & $\begin{array}{l}1.428 \\
(0.288)\end{array}$ \\
\hline & 80 & 1.784 & $\begin{array}{l}1.653 \\
(0.469)\end{array}$ \\
\hline & 90 & \multicolumn{2}{|l}{} \\
\hline
\end{tabular}

Although we do not investigate the origin of these inequalities, for example they may be explained by differential access to health care $^{18}$, our methodology correctly captures the impact of different health conditions on household's consumption decisions, controlling for simultaneous consumption choices and demographics and provides a money metric measure of the welfare loss.

Furthermore we can build on our results to ask a more general question: for each definition of equivalent income, we can compute a standard summary statistic of the income distribution, such as the Atkinson's index of inequality. If inequality increases when income is deflated by the health

\footnotetext{
${ }^{18}$ See also Skinner and Zhou (2004)
} 
equivalence scale, then on average poorer households are more affected by health conditions (they tend to have poor health). In other words an increase in inequality can be regarded as a social welfare loss due to poor health. To construct an inequality index we start from a isoelastic welfare function:

$$
W=W\left(U_{1}, \ldots, U_{h}, \ldots, U_{N_{h}}\right)=\frac{1}{N_{h}} \sum_{h=1}^{N_{h}} \frac{U_{h}^{1-\varepsilon}}{1-\varepsilon}
$$

where $U$ stands for the individual utility level (which could also be "equalised" according to one of the scales described above). For simplicity we assume that at the individual level utility is of the simple logarithmic form as specified in (1).

These assumptions allow us to derive an equally distributed equivalent income: $Y_{E D E}$, which represents the equivalent income assigned to each household, equally across households, such that the resulting level of total welfare is the same as the of level of actual welfare (the latter results from the actual income distribution). The income $Y_{E D E}$ is a monotonic transformation of the level of social welfare, hence it is the money metric representation of the actual level of welfare associated with the distribution of the equivalent household incomes. We indicate with $\bar{Y}$ the actual mean value of the income distribution, i.e. the level of income implied by the maximum welfare level which could be achieved given the current resources in the economy. The Atkinson's index of relative inequality is then:

$$
I=1-\frac{Y_{E D E}}{\bar{Y}}
$$

We can compute the Atkinson's index for different cases of relevance to us: for example we can look at the distribution of equivalent incomes based on demographic scales or on health equivalence scales or both. 
Table 8. Measures of inequality: equivalent incomes and the Atkinson's index.

\begin{tabular}{|c|c|c|c|c|c|}
\hline & $\begin{array}{l}\text { Max } \\
\text { possible } \\
\text { welfare } \\
\end{array}$ & $\begin{array}{l}\text { Actual } \\
\text { welfare } \\
\text { (EDE) } \\
\end{array}$ & $\begin{array}{l}\text { Mean tot } \\
\text { expenditure }\end{array}$ & $Y_{E D E}$ & $\begin{array}{l}\text { Atkinson } \\
\text { index }\end{array}$ \\
\hline & \multicolumn{5}{|c|}{ Inequality Aversion Parameter is $\varepsilon=0$} \\
\hline Household income & 3.21 & 2.84 & 24.77 & 17.04 & $31.10 \%$ \\
\hline $\begin{array}{l}\text { Household } \\
\text { equivalent income } \\
\text { (health) }\end{array}$ & 3.03 & 2.63 & 20.71 & 13.88 & $32.97 \%$ \\
\hline $\begin{array}{l}\text { Household } \\
\text { equivalent income } \\
\text { (age and health) }\end{array}$ & 2.34 & 1.91 & 10.39 & 6.75 & $35.07 \%$ \\
\hline \multirow[t]{2}{*}{$\begin{array}{l}\text { Household } \\
\text { equivalent income } \\
\text { (age, health, and } \\
\text { ADL3) }\end{array}$} & 2.32 & 1.89 & 10.21 & 6.59 & $35.42 \%$ \\
\hline & \multicolumn{5}{|c|}{ Inequality Aversion Parameter is $\varepsilon=1$} \\
\hline Household income & 1.17 & 1.00 & 24.77 & 15.19 & $38.66 \%$ \\
\hline $\begin{array}{l}\text { Household } \\
\text { equivalent income } \\
\text { (health) }\end{array}$ & 1.11 & 0.91 & 20.71 & 12.09 & $41.65 \%$ \\
\hline $\begin{array}{l}\text { Household } \\
\text { equivalent income } \\
\text { (age and health) }\end{array}$ & 0.85 & 0.54 & 10.39 & 5.61 & $45.99 \%$ \\
\hline $\begin{array}{l}\text { Household } \\
\text { equivalent income } \\
\text { (age, health, and } \\
\text { ADL3) }\end{array}$ & 0.84 & 0.53 & 10.21 & 5.49 & $46.25 \%$ \\
\hline
\end{tabular}

Note: mean annual total expenditure in the raw data is \$ 21930 (expressed in 2001-\$), mean expenditures have been normalised by dividing each value by the highest in the distribution and then by multiplying by 1000 .

Table 8 shows an important effect of subjective health and of the combined “age and subjective health” variation, this is even more marked accounting for the ADL3 variables. These figures reflect the result found above, that a household in poor health would need a substantial compensation to be as well off as the reference household, in fact the equally distributed equivalent income drops dramatically. This means for example, that for those households facing health problems, welfare, measured in money metric units, drops by 18 percentage points. 
In terms of the overall distribution of welfare, i.e. for the social cost of ill health, the inequality index grows of about two percentage points when we account for the equivalence scale, results are quite robust to changes in the inequality aversion parameter used in constructing the index (we present results only for $\varepsilon=0$ and $\varepsilon=1$, the index obviously increases when the inequality aversion increases) ${ }^{19}$. In other words the inequality index signals that equivalent incomes are significantly more unequally distributed than actual incomes.

\section{Conclusions}

This paper provides estimates of the effect of health on welfare by specifying a demand system on HRS data, a sample based on the population aged 50 and over in the U.S.A.. We use both the CORE questionnaire (mainly for the health variables) and the CAMS questionnaire (for the household budget), to cover the years 2001 and 2003. We specify seven broad commodities, including "health-expenditure", food, "free- time expenditure" etc...

Our model adopts the two-stage budgeting approach, so that estimates of the demand system parameters are conditional on life cycle variables. Furthermore health variables are coded one year before the budget information is collected - hence we can argue that health conditions are predetermined vis-á-vis health-expenditure decisions. Our estimates show that health expenditures are strongly affected by health conditions: ill health is associated with a higher budget share for health related goods, after controlling for a number of household characteristics, including age, an ADL index, disability, education etc...

On the basis of these estimates we derive equivalence scales which suggest that households in poor health should be "compensated" to reach the same

\footnotetext{
${ }^{19}$ It should be recalled that the index looks at the overall welfare distribution and one percentage point change is quite a large effect in this respect. In fact this "income" distribution exhibits more inequality if more households in poor health are located at the lower tail of the distribution.
} 
level of welfare as similar households in good health conditions. In particular, a household facing poor health, with the same actual total expenditure of a healthy household, would have an equivalent income curtailed of one third because of the "true" cost of health. We obtain a money metric measure of this reduction in welfare: "equally distributed equivalent” incomes drop of 18 percentage points for households in poor health.

Furthermore calculations of the inequality index based on the equally distributed equivalent incomes show a substantial degree of overall welfare inequality due to ill health (the Atkinson's index grows of about two percentage points). When coupled with growth in age the same measure shows a more marked increase in inequality: older people in poor health suffer important disparities when compared with the reference household. These findings suggest important social welfare costs of the existing differences in health conditions of the elderly population in the USA. 


\section{References}

Adda, J., J. Banks and H. von Gaudecker (2005), The Impact of Income

Shocks on Health: Evidence from English Cohorts, University College, London

Atkinson, A. (1970), On the Measurement of Inequality”, Journal of Economic Theory, September,

Baicker, K. and A. Chandra, (2004) "Medicare Spending, the Physician Workforce, and Beneficiaries’ Quality of Care” Health Affairs (April 7).

Battacharya, J., and D. Lakdawalla, (2004) "Does Medicare Benefit the Poor? New Answers to an Old Question,” NBER Working Paper No. 9215

Blundell R. P. Pashardes and G. Weber (1993) "What do we Learn About Consumer Demand Patterns from Micro Data?”, American Economic Review, 83, 570-597

Case, A., D. Lubotsky and C.Paxson, (2002), Economic Status and Health in Childhood: the Origins of the Gradient, American Economic Review, 92, no. 5, p. 1308-34.

Currie J. and B. Madrian (1999), Health, Health Insurance and the Labor Market, in O. Ashenfelter and D. Card (eds.) Handbook of Labor Economics, vol. 3, p.3309-3415

Deaton A., Muellbauer J. (1980a) “An Almost Ideal Demand System”, American Economic Review, 70, pp. 312-326.

Deaton A., Muellbauer J. (1980b) Economics and Consumer Behavior, CUP, Cambridge.

Deaton A., (2001) Relative deprivation, inequality and mortality, NBER, wp 8099 
Grossman M. (1972a) The Demand for Health: A Theoretical and Empirical Investigation, New York, NBER.

Grossman M. (1972b) "On the concept of Health Care and Demand for Health”, Journal of Politica Economy, 80, 2, pp. 223-255.

Hurd M and S, Rohwedder (2005) "The Retirement Consumption Puzzle, Anticipated and Actual Declines in Spending at Retirement”, RAND Labor and Population WR242

Jorgenson D.W., Slesnick D.T. (1986) “Aggregate Consumer Behavior and the Measurement of Social Welfare”, Econometrica, 58, 5, pp. 1007-1040. Le Grand, Julian, “The Distribution of Public Expenditure: The Case of Health Care,” Economica 45(178) (May 1978): 125-142.

Le Grand, J. (1982), The Strategy of Equality. London, George Allen \& Unwin .

Le Grand, J. (1991), “The Distribution of Health Care Revisited: A Commentary on Wagstaff, van Doorslaer and Paci, and O’Donnell and Propper,” Journal of Health Economics 10 - 239-245.

Lee, J., M. McClellan, and J. Skinner, (1999) "The Distributional Effects of Medicare Expenditures,” in J. Poterba (ed.) Tax Policy and the Economy 13

Patrizii V., Rossi N. (1991) Preferenze, prezzi relativi e redistribuzione, Il Mulino, Bologna.

RAND (2005) RAND HRS Data Description, Version E, RAND for the Study of Aging

Skinner J. and W. Zhou (2004) “The Measurement and Evolution of Health Inequality”, in A.J. Auerbach, D. Card, and J.M Quigley (eds.) Poverty, 
The Distribution of Income, and Public Policy. New York: Russell Sage Foundation. (NBER Working Paper No. 10842)

Smith J. (1999) "Healthy bodies and thick wallets: the dual relationship between health and economic status”, Journal of Economic Perspective, 13, 2, 145-166.

Smith J. (2004), Unraveling the SES Health Connection, IFS working paper WP04/02

Wagstaff A. (1986) “The Demand for Health: a Simplified Grossman model”, Journal of Epidemiology and Community Health, 40, pp. 1-11.

Williams A. (1997) Being reasonable about the Economics of Health, Edward Elgar.

http://hrsonline.isr.umich.edu/meta/rand/randhrse/randhrse.pdf 
Table A1. Variables used in the regression analysis, mean and standard deviation for the years 2001 and 2003 (incomes and expenditures are in dollars of the year 2001)

\begin{tabular}{||l|l|l||}
\hline VARIABLE & MEAN & STD. DEV. \\
\hline Health Goods (Budget Share) & 0.1264 & 0.127 \\
\hline Food (Budget Share) & 0.1686 & 0.123 \\
\hline House Services (Budget Share) & 0.2112 & 0.148 \\
\hline "Free Time” (Budget Share) & 0.0998 & 0.117 \\
\hline Clothing (Budget Share) & 0.0563 & 0.065 \\
\hline Transportation (Budget Share) & 0.0766 & 0.079 \\
\hline Logarithm of Total Real Expenditure & 9.6199 & 0.753 \\
\hline Households with one member & 0.4489 & 0.492 \\
\hline Head is Male & 0.4649 & 0.496 \\
\hline Logarithm of Age of Head & 4.2169 & 0.138 \\
\hline One Member has low education & 0.1193 & 0.323 \\
\hline Both Members have low education & 0.0155 & 0.123 \\
\hline One Member has high education & 0.2578 & 0.436 \\
\hline Both Members have high education & 0.0623 & 0.241 \\
\hline One Member is retired & 0.5764 & 0.464 \\
\hline Both Members are retired & 0.1550 & 0.335 \\
\hline One Member non employed, but not retired & 0.2138 & 0.382 \\
\hline Both Members are non employed, but not retired & 0.0011 & 0.029 \\
\hline One Member is disabled & 0.0792 & 0.256 \\
\hline Both Members are disabled & 0.0081 & 0.084 \\
\hline Index for “poor health” & 0.2544 & 0.405 \\
\hline Index for “fair health” & 0.3654 & 0.426 \\
\hline One or both members with no more than one ADL3 & 0.0915 & 0.253 \\
\hline One or both members with more than one ADL3 & 0.0525 & 0.207 \\
\hline Head has private health insurance & 0.7524 & 0.396 \\
\hline Head enrolled in Medicare & 0.6776 & 0.451 \\
\hline Head enrolled in Medicaid & 0.0658 & 0.238 \\
\hline Head currently smoker & 0.1809 & 0.374 \\
\hline Head drinking alcohol & 0.473 \\
\hline \hline
\end{tabular}

(continues) 


\begin{tabular}{||l|l|l||}
\hline VARIABLE & MEAN & STD. DEV. \\
\hline Middle Atlantic & 0.1296 & 0.333 \\
\hline East North Central & 0.1707 & 0.373 \\
\hline West North Central & 0.0980 & 0.295 \\
\hline South Atlantic & 0.2316 & 0.417 \\
\hline East South & 0.0591 & 0.234 \\
\hline West South & 0.0821 & 0.027 \\
\hline Mountain & 0.0543 & 0.022 \\
\hline Pacific & 0.1185 & 0.032 \\
\hline Number of observations & 3054 & \\
\hline \hline
\end{tabular}

